\title{
INFLUENCE OF SOWING DATES ON STEMPHYLIUM BLIGHT DISEASE SEVERITY AND YIELD PERFORMANCE OF LENTIL AT RAMPUR, CHITWAN, NEPAL
}

\author{
S. Subedi ${ }^{1}$, S.M. Shrestha ${ }^{2}$, G.B. Khatri-Chhetri ${ }^{2}$ and R.B. Thapa ${ }^{2}$, \\ S.K. Ghimire ${ }^{3}$, D.B. Gharti ${ }^{1}$ and S. Neupane ${ }^{1}$ \\ ${ }^{1}$ Nepal Agriculture Research Council, Kathmandu, Nepal, ${ }^{2}$ Institute of Agriculture and Animal \\ Sciences, Tribhuvan University, Nepal, ${ }^{3}$ Agriculture and Forestry University, Chitwan, Nepal
}

\begin{abstract}
A study on lentil (Lens culinaris Medik) was carried out at Rampur, Chitwan with different sowing dates under field conditions to assess the severity of Stemphylium blight disease severity and yield performance during two consecutive years 2012-2014. During 2012/013, lower (3.00) and higher disease severity (6.50) were recorded on lentil plants sown on November 6 and December 16, respectively. Early sown lentil resulted in higher yield $(2025 \mathrm{~kg} / \mathrm{ha})$ followed by late shown one $(1213 \mathrm{~kg} / \mathrm{ha})$. Similarly, trends of disease development were similar in succeeding year (2013/14). Lentil seed shown on November 1 had lower disease severity (3.50) and produced higher yield $(962.50 \mathrm{~kg} / \mathrm{ha})$ compared to that were shown on later dates. Disease severity increased with the advancement of sowing date from November 1 to December 21 with decreased yields. Hence, over years, early shown lentil (November 1, 6 and 11) escaped the higher severity of Stemphylium blight with the increase in yield.
\end{abstract}

Key Words: Lentil, sowing dates, Stemphylium blight, yield, disease severity

\section{INTRODUCTION}

Lentil (Lens culinaris Medik) is one of the oldest cultivated crops and has been a major food source of many civilizations for more than 8000 years (Oplinger et al., 1990). Lentil is a major grain and widely distributed legume crop grown under a broad range of climates in many developing countries (Turk et al., 2004; Abd-Allah and Hashem, 2006). This crop has been grown mainly as an inexpensive source of high quality protein in human diets (Salehpour et al., 2009; Rahman et al., 2010). In Nepal also, lentil is the most important and highly commercialized pulse among the grain legumes in terms of area (206522 ha), production (226931 mt) and productivity (1099 kg/ha) which shares almost $62 \%$ of total area and $65 \%$ of total production of pulses and rates the highest consumer preference (MOAD, 2013).

At present, the yield of lentil at national level is far below than its yield potential. Production is decreasing every year due to biotic and abiotic yield limiting factors, susceptibility to disease, low acreage and delay in sowing by the farmers. Lentil crop is affected by a wide range of pathogens. Fungal diseases decrease in productivity through infection and damage to leaves, stems, roots and pods as well as reduce marketability by discolouring seeds (Taylor et al., 2007). Stemphylium blight that associated with Stemphylium botryosum Walr is the most important disease of lentil in Nepal (Joshi, 2006; Gharti et al., 2008). In Nepal, it was first reported during 1993. This disease has become widespread throughout major lentil growing areas of the country (Bayaa et al., 1998). Stemphylium botryosum causes leaf blight that can result in large scale defoliation of plants. Preliminary studies in Bangladesh and India estimated yield losses of $62 \%$ and total crop failure have been reported in some cases where the disease defoliated the crop in the early pod setting stage (Bakr, 1991; Erksine and Sarker, 1997). In recent years, Stemphylium blight has been observed increasing in lentil fields in Banke, Bardia, 
Rupandehi, Chitwan, Nepalgunj, Makwanpur, Bara, Parsa and Rautahat districts (Joshi, 2006). Because of the adverse environmental effects of fungicide application, there is a need to explore the potential alternative strategies including the manipulation of agronomic practices for disease control (Jacobsen and Backman, 1993). Control of plant disease becomes successful and economical when management approach involving several methods are employed including chemical means (Bakr and Ahmed, 1992), cultural practices (Howlider et al., 1989) and use of resistant varieties (Ahmed, 1986). Many field crops can escape various diseases with the shifting of sowing time (Sud and Singh, 1984; Hedge and Anahosur, 1994). The study was designed to study the effect of sowing dates on Stemphylium blight severity and yield performances of lentil.

\section{MATERIALS AND METHODS}

The experiment was conducted during winter season of 2012-2013 and 2013-2014. The experiment was laid out in Randomized Complete Block Design with four replications. During 20122013, a susceptible variety Shital was shown on 5 different dates, viz. November 6, 16, 26, December 6 and 16 in a unit plot size of $4 \mathrm{~m} \times 0.5 \mathrm{~m}$ with $25 \mathrm{~cm}$ row to row spacing. All procedures were similar except showing dates, viz., November 1, 11, 21, December 1, 11 and 21 in a unit plot size of $4 \mathrm{~m} \mathrm{x}$ $2 \mathrm{~m}$ during 2013-2014. After completion of the sowing, the experiment was kept under constant watch from sowing up to harvest. Agronomic practices were followed as recommended. The recommended dose of fertilizers (N:P:K) used in the experiment was $20: 40: 20 \mathrm{Kg} / \mathrm{ha}$. The data on meteorological factors, such as atmospheric temperature, relative humidity and rainfall with corresponding sowing dates were recorded.

\section{Observation}

The disease data were recorded from 25 randomly tagged plants/plot on the basis of 1-9 scoring scale (Morrall and Mckenzie, 1974).

$1=$ No lesion visible (Highly resistant)

$3=$ Few scattered lesions, usually visible after careful searching (Resistant)

$5=$ Lesions common on plants and easily observed but defoliation and/ or damage not great, or in only one or two patches in plot (Moderately resistant)

$7=$ Lesions very common and damaging (Susceptible)

9= Lesions extensive on all plants, defoliation and drying branches, and killing of some plants (Highly susceptible)

Percent Disease Index (PDI) was computed on the basis of recorded data according to the formula (Wheeler, 1969) and Percent Disease Control (PDC) was calculated on the basis of the formula developed by Shivankar and Wangikar, 1993.

$$
\begin{aligned}
& \text { PDI }=\frac{\text { Sum of numerical values }}{\text { No of plant parts observed }} \times \frac{100}{\text { Maximum diseases rating }} \\
& \mathrm{PDC}=\frac{\text { Disease in control plot }- \text { Disease in treated plot }}{\text { Disease in control plot }} \times 100
\end{aligned}
$$

Early Plant Stand (EPS) and Final Plant Stand (FPS) were recorded by the scale developed by International Centre for Agricultural Research in the Dry Areas, Aleppo, Syria (2011).

$1-90 \%$ or more $=$ very good

2- $80-89 \%=\operatorname{good}$ 
3- $70-79 \%=$ acceptable

4- $60-69 \%=$ poor

5- Less than $60 \%=$ very poor

Data were recorded on yield and yield attributes. Yield increase over the control was calculated. The temperature, moisture, relative humidity and rainfall were also recorded during experiment period.

\section{Data Analysis}

All data were analyzed statistically using the computer package program MSTAT-C. Treatment means were compared using Least Significance Difference (LSD) and Duncan's Multiple Range Test (DMRT) at 5\% levels of significance. The correlation among percent yield increased over control and percent disease control was calculated.

\section{RESULTS AND DISCUSSION \\ Disease development with relation to different sowing dates}

Early plant Stand (EPS), Disease Severity (DS), Percent Disease Index (PDI), Final Plant Stand (FPS), Yield and Hundred Seed Weight (HSWT) significantly varied among the sowing dates at condition of Rampur Chitwan during the year 2012-2013. Plant stand, yield and hundred seed weight were higher in early sowing date and decreased with the advancement in sowing dates. The lower disease severity (3.00) and PDI (40.65\%) was recorded in sowed plants in November 6 and the severity increased with the advancement of sowing dates, i.e. higher PDI (65.77\%) in lentil plots sown on December 16. The experimental plot sown on November 1 had highest yield $(2025 \mathrm{~kg} /$ ha) and hundred seed weight $(1.65 \mathrm{gm})$ both followed by the plot sown on November 16 . The lowest yield $(950 \mathrm{~kg} / \mathrm{ha})$ was obtained from the plot sown on December 16 . The higher percent disease control (PDC) and Percent Yield increase (PYI) both, i.e. 38.20\% and 113.16\%, respectively was found in the plot sown on November 6 followed by crop sown on November 16 compared to plot sown on December 16 (Table 1).

\section{Relationship between yield and percent disease index}

A linear negative correlation between yield and PDI was observed during 2012/013. Equation $\mathrm{Y}=18.99 \mathrm{X}+2132$ and $\mathrm{R}^{2}=0.940$ gave the best fit (Figure 1). It was noted that yield was decreased with the increase in Percent Disease Index (PDI).

Table1. Effect of sowing date on disease severity and yield performance of lentil at Rampur, Chitwan during 2012/013

\begin{tabular}{|c|c|c|c|c|c|c|c|c|}
\hline Sowing date & $\begin{array}{l}\text { EPS } \\
(\%) \\
\end{array}$ & $\begin{array}{l}\text { DS } \\
\text { (1-9 scale) }\end{array}$ & PDI & $\begin{array}{l}\text { FPS } \\
(\%) \\
\end{array}$ & $\begin{array}{l}\text { YIELD (kg/ } \\
\text { ha) }\end{array}$ & $\begin{array}{l}\text { HSWT } \\
\text { (gm) }\end{array}$ & $\begin{array}{l}\text { PDC } \\
(\%)\end{array}$ & $\begin{array}{l}\text { YI } \\
(\%) \\
\end{array}$ \\
\hline November 6 & $96.25^{a^{\dagger}}$ & $3.00^{\mathrm{c}}$ & $40.65^{d}$ & $88.75^{a}$ & $2025.00^{\mathrm{a}}$ & $1.65^{\mathrm{a}}$ & 38.20 & 113.16 \\
\hline November 16 & $94.00^{\mathrm{ab}}$ & $4.00^{\mathrm{bc}}$ & $47.75^{c}$ & $86.25^{a}$ & $1213.00^{b}$ & $1.57^{\mathrm{a}}$ & 27.40 & 27.68 \\
\hline November 26 & $92.50^{\mathrm{b}}$ & $4.00^{b c}$ & $50.22 \mathrm{bc}$ & $85.00^{\mathrm{a}}$ & $1188.00^{b c}$ & $1.50^{a b}$ & 23.64 & 25.05 \\
\hline December 6 & $89.25^{\mathrm{c}}$ & $5.00^{\mathrm{b}}$ & $54.25^{\mathrm{b}}$ & $80.00^{b}$ & $1156.00^{\mathrm{bc}}$ & $1.35^{b c}$ & 17.52 & 21.68 \\
\hline December 16 & $80.25^{\mathrm{d}}$ & $6.50^{\mathrm{a}}$ & $65.77^{\mathrm{a}}$ & $72.50^{\mathrm{c}}$ & $950.00^{\mathrm{c}}$ & $1.30^{\mathrm{c}}$ & - & - \\
\hline F-Test & $* *$ & $*$ & $* *$ & $* *$ & $* *$ & $*$ & & \\
\hline LSD $(\leq \mathbf{0 . 0 5})$ & 2.56 & 1.19 & 5.39 & 4.16 & 238.11 & 0.15 & & \\
\hline $\mathrm{CV} \%$ & 1.84 & 17.21 & 6.77 & 3.27 & 11.83 & 6.77 & & \\
\hline
\end{tabular}

${ }^{\dagger}$ Means of 4 replication. Means in column with same superscript is not significantly different by LSD $(\mathrm{P}<0.05$. EPS - Early Plant Stand per plot, DS - Disease severity, PDI- Percent Disease Index, FPS Final Plant Stand/plot, YIELD- Grain yield, HSWT- Hundred Seed Weight, PDC- Percent Disease Control, YI- Yield Increase, **- Highly Significant, * - Significant. 


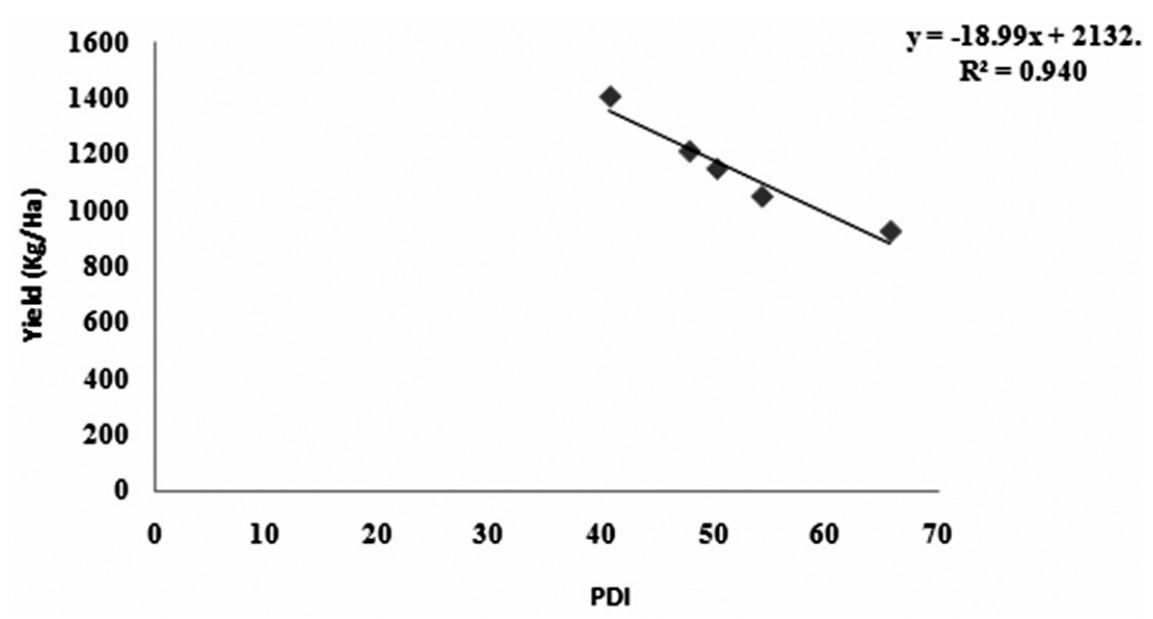

Figure1. Relationship between PDI and Yield in different sowing dates of lentil at Rampur, Chitwan during 2012/013

During (2013/014) also, trends of both disease development and yield were similar. Early sown plots had good plant stand and yield parameters than late sown crops. The higher percent disease index was recorded on crops sown on December 21 (69.10\%). The crop shown on November 1 had lowest PDI (47.08\%) followed by November 11. Final plant stand was also noticed higher in early shown plots. Yield and hundred seed weight both were recorded highest in the plot shown on November 1, i.e. $962.50 \mathrm{~kg} / \mathrm{ha}$ and $1.68 \mathrm{gm}$ followed by November 11 . The lowest yield was found from the late sown plot December $21(318.75 \mathrm{~kg} / \mathrm{ha})$. Both the higher percent disease control (PDC) and Percent Yield increase (PYI), i.e. $31.87 \%$ and $201.96 \%$, respectively were found in the plot sown on November 1 followed by crop sown on November 11 and consequently that sown on December 21(Table 2).

Table2. Effect of time of sowing on disease severity and yield of lentil at Rampur, Chitwan during 2013-2014

\begin{tabular}{|c|c|c|c|c|c|c|c|c|}
\hline Sowing Date & $\begin{array}{c}\text { EPS } \\
\%\end{array}$ & $\begin{array}{c}\text { DS } \\
(1-9) \\
\end{array}$ & PDI & FPS \% & $\begin{array}{c}\text { Yield } \\
(\mathrm{Kg} / \mathrm{ha})\end{array}$ & $\begin{array}{c}\text { HSWT } \\
\text { (gm) }\end{array}$ & $\begin{array}{c}\text { PDC } \\
(\%)\end{array}$ & $\begin{array}{l}\text { YI } \\
(\%)\end{array}$ \\
\hline November 1 & $90.00^{a^{\dagger}}$ & $3.50^{\mathrm{d}}$ & $47.08^{\mathrm{d}}$ & $85.00^{a}$ & $962.50^{a}$ & $1.68^{\mathrm{a}}$ & 31.87 & 201.96 \\
\hline November 11 & $88.75^{a}$ & $3.50^{\mathrm{d}}$ & $50.72^{\mathrm{c}}$ & $83.75^{a}$ & $837.50^{b}$ & $1.61^{\mathrm{b}}$ & 26.60 & 162.74 \\
\hline November 21 & $80.00^{\mathrm{b}}$ & $4.00^{\mathrm{cd}}$ & $53.40^{\mathrm{c}}$ & $73.75^{b}$ & $737.75^{c}$ & $1.43^{\mathrm{c}}$ & 22.72 & 131.45 \\
\hline December 1 & $71.25^{\mathrm{c}}$ & $5.00^{b c}$ & $65.45^{b}$ & $66.75^{\mathrm{c}}$ & $607.50^{d}$ & $1.37^{\mathrm{d}}$ & 5.28 & 90.58 \\
\hline December 11 & $67.25^{\mathrm{cd}}$ & $6.00^{a b}$ & $66.92^{a b}$ & $62.50^{\mathrm{cd}}$ & $557.50^{\mathrm{e}}$ & $1.25^{\mathrm{e}}$ & 3.15 & 74.90 \\
\hline December 21 & $62.75^{\mathrm{d}}$ & $7.00^{\mathrm{a}}$ & $69.10^{a}$ & $58.75^{\mathrm{d}}$ & $318.75^{\mathrm{f}}$ & $1.21^{\mathrm{e}}$ & - & - \\
\hline F-Test & $* *$ & $* *$ & $* *$ & $* *$ & $* *$ & $* *$ & & \\
\hline LSD $(\leq 0.05)$ & 6.26 & 1.10 & 2.86 & 6.80 & 44.18 & 0.04 & & \\
\hline CV\% & 5.42 & 15.11 & 3.23 & 6.29 & 4.36 & 1.92 & & \\
\hline
\end{tabular}

${ }^{\dagger}$ Means of 4 replication. Means in column with same superscript is not significantly different by DMRT $_{(\mathrm{P}<0.05) \text {. }}$ EPS - Early Plant Stand per plot, PDI- Percent Disease Index, FPS - Final Plant Stand/ plot, YIELD- Grain yield, HSWT- Hundred Seed Weight, PDC- Percent Disease Control, YI- Yield Increase, ${ }^{* *}$ - Highly Significant, 


\section{Relationship between Percent Disease Control (PDC) and Percent Yield Increase (PYI)}

A positive linear correlation between Percent Disease Control (PDC) and Percent Yield Increase (PYI) was observed during 2013/014. Equation $\mathrm{Y}=3.885 \mathrm{X}+62.67$ and $\mathrm{R}^{2}=0.940$ gave the best fit (Figure 2). It was noted that yield was increased with the decrease in disease severity.

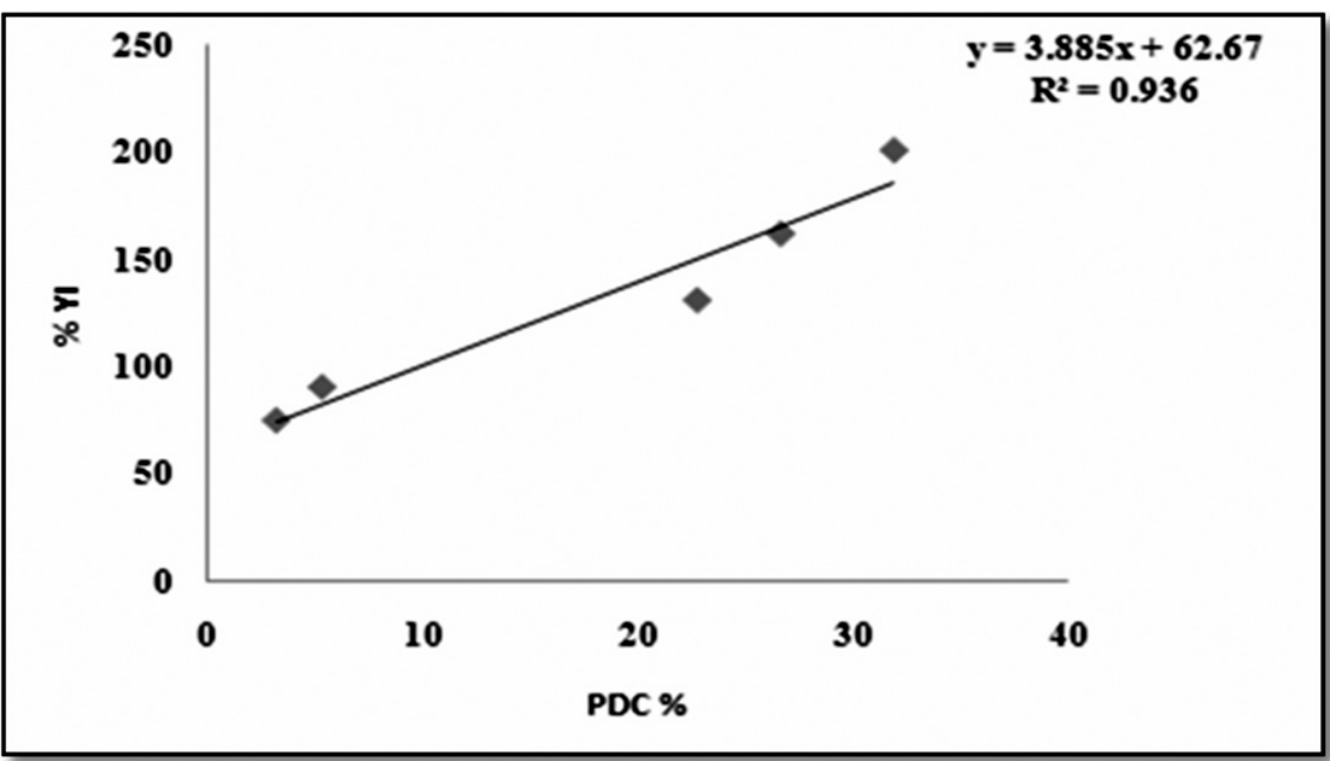

Figure2. Relationship between PDC and PYI in different sowing dates of lentil at Rampur, Chitwan during 2013/014.

The trends of disease incidence and its effect on yield were almost similar during the research period. Gradual increase in disease severity along with the advancement of sowing dates resulted in to reduction in yield. From the observations of two years study, it is clear that Percent Disease Index (PDI) was less in early sowing compared to that of late sowing. Sowing up to middle of November, lentil could escape the infection of Stemphylium blight significantly and result in to increase in yield. The findings of the present study is in close agreement with the findings of (Huq and Khan, 2007), who reported that in the sowing of November 1, 10 and 20, lentil could escape the infection of Stemphylium blight and yield was also maximum in early sown crops. Time of sowing for any crop is a very important factor for growth and multiplication of plant pathogens. Lentil as winter crop is highly sensitive to variation of climatic conditions (Jain et al., 1987). This is one of the predisposing factors for building up of different diseases of a crop. Sowing time has marked effect upon the level of disease incidence where with the manipulation of sowing dates incidence/ severity of disease may be reduced (Hedge and Anahusor, 1994). It is evident from the study that the incidence of Stemphylium blight could be avoided when lentil is sown early, i.e. within second week of November. This observation was in close agreement with that of (Gupta, 1985), who reported that early sown crop suffered less by cercospora leaf spot of groundnut where as late sown crop suffered maximum because of inoculum pressure in the atmosphere. In mustard crop, progressive increase in infection rate of pod blight and decrease in yield was found in delay sowing (Howlider et al., 1989), which is in close agreement of the present findings. Delayed sowing greatly increased the incidence of anthracnose of French beans (Sindhan and Bose, 1981). 


\section{CONCLUSION}

The findings of two consecutive years showed almost similar trends regarding yield and disease severity. From this study, it is clear that Percent Disease Index (PDI) was less in early sowing compared to that of late sowing of lentil. In the sowing up to Second week of November, lentil could escape the infection of Stemphylium blight significantly and resulted in to increase in yield. The severity increased with the advancement of sowing date from November 1 to December 21 . The lentil yield was decreased with the progression of sowing dates. Over years, early sowing lentil (November 1, 6 and 11) crop has less chances of attack of Stemphylium blight. Thus, it is recommended that lentil should be sown as early as possible in November for maximum yield with the reduction of disease severity significantly.

\section{ACKNOWLEDGEMENTS}

The authors are grateful to Grain Legume Coordinator for continuous support to carry out the experiments and providing physical facilities to prepare this report. Thanks are extended to Plant Pathology Division of NARC for making arrangements and valuable suggestions to conduct experiments. Help in conducting experiments and data recording from Technician T.N. Ghimire and Scientist S. Neupane and other supporting staffs are highly appreciated.

\section{REFERENCES CITED}

Abd-Allah, E.F. and A. Hashem. 2006. Seed mycoflora of Lens esculenta and their biocontrol by chitosan. Phytoparasitica 34:213-218.

Ahmed, H.U. 1986. Recommendation in the methods of disease management of crop in Bangladesh. Plant Pathology Division. Bangladesh Agricultural Research Institute, Joydebpur, Gazipur, Bangladesh. pp. 11-12.

Bakr, M.A. 1991. Plant protection of lentil in Bangladesh. In: Proceedings of the Seminar on Lentil in South Asia, 11-15 March, 1991. New Delhi, India. pp. 7-12.

Bakr, M.A. and F. Ahmed. 1992. Development of Stemphylium blight of lentil and its control. Bangladesh J. Plant Pathol. 8 (1\&2):39-40.

Bayaa, B., S. Joshi, P.B. Karki and P. Jha. 1998. Lentil disease survey report. 23rd February, 1998, Kathmandu, Nepal.

Bayaa, B. and W. Erskine. 1998. Lentil pathology. In: D. Allen and J. Lenné (eds.) Pathology of Food and Pasture Legumes. Commonwealth Agricultural Bureaux International, U.K in association with: International Crop Research Center for the Semi-Arid Tropics, Patancheru 502324. Andhra Pradesh, India. pp. 423-472.

Erskine, W. and A. Sarker. 1997. Lentil: The Bangladesh breakthrough. ICARDA Carvan No. 6. Aleppo, Syria.

Gharti, D.B., P. Jha, R. Darai, D. Ghale, S. Joshi and B.P. Wagle. 2008. Studies on management of Stemphylium blight (Stemphylium sarciniforme) of lentil (Lens culinaris L.) at NGLRP, Rampur and RARS, Nepalgunj. In: Program and Abstract of a $27^{\text {th }}$ National Winter Crops 
Workshop "Ensuring Food Security through Crop Diversification". Nepal Agricultural Research Council. pp. 35-36.

Gupta, D.K. 1985. Effect of date of sowing on the occurrence of cercospora leaf spots of groundnut in Manipur. Indian Phytopath. 38: 738-740.

Hedge, V.M. and K.H. Anahosur. 1994. Influence of sowing dates of mustard on the epidemiology of white rust. Indian Phytopath. 47(4): 391-394.

Howlider, M.A., K. Anzuman-Ara, M. Bagum and A. Rahman. 1989. Effect of date of sowing and pod blight severity and yield of mustard. Bangladesh J. Plant Path. 5 (1\&2): 41-46.

Huq, M. Ishanul and A.Z.M. Nowsher Ali Khan. 2007. Effect of sowing dates on the incidence of Stemphylium blight of lentil during 1998-2001. Bangladesh J. Sci. Ind. Res. 42(3): 341-346.

Jacobsen, B.J. and P.A. Backman. 1993. Biological and cultural plant disease control: Alternatives and supplements to chemicals in IPM systems. Plant Dis. 77: 311-315.

Jain, P.C., D.S. Khuswah and V.K. Jain. 1987. Yield of lentil cultivar as affected by date of sowing. Legume Res. 10: 84-86.

Joshi, S. 2006. Review of important grain legume diseases and their management. In: Proceedings of a National Workshop on Integrated Pest Management (IPM). Plant Protection Society of Nepal. pp. 100-116.

MOAD, 2013. Statistical information on Nepalese Agriculture 2069/70. Agri-Business Promotion and Statistics Division, Ministry of Agriculture Development, Kathmandu, Nepal.

Morrall, R.A.A. and D.L., Mckenzie. 1974. A note on the inadvertent introduction to North America of Ascochyta rabiei, a destructive pathogen of chickpea. Plant Dis. Reporter. 58:342-345.

Oplinger, E.S., L.L. Hardman, A.R. Kaminski, K.A. Kelling and J.D. Doll. 1990. Lentil: Alternative field crops manual. University of Wisconsin-Extension, Cooperative Extension and University of Minnesota; Center for Alternative Plant \& Animal Products and the Minnesota Extension Sevice. Retrieved December 10, 2014, from http://www.purdue.edu/newcrop /afcm/lentil. $\underline{\mathrm{html}}$.

Rahman, T., A.U. Ahmed, M.R. Islam and M.I. Hosen. 2010. Physiological study and both in vitro and in vivo antifungal activities against Stemphylium botryosum causing Stemphylium blight disease in lentil (Lens culinaris). Plant Pathol. J. 9: 179-187.

Salehpour, M., A. Ebadi, M. Izadi and Sh. Jamaati-e-somarin. 2009. Evaluation of water stress and nitrogen fertilizer effects on relative water content, membrane stability index, chlorophyll and some other traits of lentil (Lens culinaris L.) under hydroponic conditions. Res. J. Environ. Sci. 3: 103-109.

Shivankar, S.K. and P.D. Wangikar. 1993. Effect of different fungicides on the control of gray mildew disease of cotton. Indian Phytopath. 46 (3): 230-235. 
Sindhan, G.S. and S.K. Bose. 1981. Epidemiology of anthracnose of French bean caused by Colletotrichum lindemuthianum. Indian Phytopath. 34(4): 484-487.

Sud, V.K. and B.M. Singh. 1984. Effect of sowing dates and row spacing on the development of leaf spot (Cercospora canescens) on Urdbean. Indian Phytopath. 37: 288-293.

Taylor, P., K. Lindbeck, W. Chen and R. Ford. 2007. Lentil diseases. In: S.S. Yadav, D. McNeil and P.C. Stevenson (eds.) Lentil: An Ancient Crop for Modern Times. Springer, Dordrecht. The Netherlands. pp. 291-313.

Turk, M.A., A.R.M. Tawaha and K.D. Lee. 2004. Seed germination and seedling growth of three lentil cultivars under moisture stress. Asian J. Plant Sci. 3: 394-397.

Wheeler, B.E.J. 1969. An introduction to plant diseases. John Wiley and Sons. Ltd. London. 301 p. 